Articles

Disponível em português: < 10.15448/1984-7289.2017.3.29445>

\title{
From reciprocal recognition to a society that is properly 'social' \\ On Axel Honneth's recent work
}

\author{
Do reconhecimento recíproco à sociedade \\ efetivamente social
}

Considerações sobre a obra recente de Axel Honneth

(1) Luiz Gustavo da Cunha de Souza*

\begin{abstract}
This paper addresses Axel Honneth's recent endeavors to defend his theory of justice, broadly described in Freedom's right (2011) as an analysis of society. The paper begins by exposing Honneth's model as a theory of institutional intersubjectivity rather than a theory of the struggle for recognition. This model, however, was subject to criticism due to its supposed acceptance of the capitalistic market economy as a social order. In order to defend it from such objections, Honneth (2016) exposes the normative core of socialist ideals as a version of social freedom. Finally, he presents a distinction between two forms of political intervention: an internal and an external struggle for recognition - and asserts the advantages of the former.
\end{abstract}

Keywords: Reciprocal recognition. Institutional intersubjectivity. Social freedom. Socialism. Struggle for recognition.

Resumo: Este artigo apresenta uma discussão sobre a obra recente de Axel Honneth. Começando por uma exposição de seu projeto teórico mais amplo, descrito em $O$ direito da liberdade (2011) como uma teoria da justiça sociologicamente ancorada, o artigo demonstra como Honneth se move da ideia de uma luta por reconhecimento em direção à ideia de intersubjetividade institucional. Este movimento, porém, é acompanhado por críticas que vêm nesta passagem o abandono das ambições críticas de seu modelo e um compromisso reformista com a ordem capitalista de mercado. A fim de responder a estas objeções, Honneth propõe uma reatualização da ideia do socialismo (2015) a partir da noção de liberdade social, concluindo com uma distinção entre duas formas de luta por reconhecimento, uma interna e outra externa - e defendendo as vantagens da primeira.

Palavras-chave: Reconhecimento recíproco. Intersubjetividade institucional. Liberdade social. Socialismo. Luta por reconhecimento.

\footnotetext{
* PhD in Sociology by the Universidade Estadual de Campinas (Unicamp, Campinas, SP, Brazil), professor at the Departament of Sociology and Political Sciences of the Universidade Federal de Santa Catarina (UFSC), in Florianópolis, SC, Brazil < gustavo.cunha.s@ufsc.br>.
}

Civitas, Porto Alegre, v. 17, n. 3, e98-e114, Sept.-Dec. 2017

Exceto onde especificado diferentemente, a matéria publicada neste periódico

é licenciada sob forma de uma licença

Creative Commons Attribution-NonCommercial-NoDerivatives 4.0 International License 


\section{Introduction}

After his debate with Nancy Fraser (Fraser and Honneth, 2003), Axel Honneth seems to gradually move away from the idea of a struggle for recognition. Since his first attempt to approach the Hegelian philosophy of right (Honneth, 2001), he seems to move in the direction of a theory of justice centred on the notion of ethical life, one in which the struggle for recognition occupies a rather smaller role than in his first book, which was still heavily influenced by George Herbert Mead's interactionist theory (Honneth, 2003 [1994]). Reciprocal recognition then is no more the goal of a social or individual struggle, but a structural, albeit implicit, element of modern social order. This movement, from an interactionist conception of recognition towards an institutional one is characterized by two main traits: On the one hand, the normative horizon of the theory is changed, leaving aside the expectation of the subjects of social interaction in favour of the institutional context where such interaction occurs; Second, negative experiences associated with injustice are not theorized as misrecognition, but as social pathologies. The culminating point of these changes is found in Freedom's Right (2011), which presents a theory of justice that is founded on the normative reconstruction of ideals and values that underlie modern democratic societies. Among those values and ideals, the idea of freedom is seen as central within the modern normative order. Thus Honneth's subject are the institutional conditions upon which freedom can be exercised within modern societies.

Such a change towards the analysis of the institutional context of modern societies, however, implies an additional move, which would prove controversial among some of Honneth's debaters. Besides the modern institutional context, it is also necessary to investigate the spheres of collective action from the viewpoint of their specific contribution to the implementation of the modern principle of individual autonomy. Accordingly, Honneth explores personal relationships, the division of labour, the economic market, representative politics and the public sphere in order to uncover their respective contributions to the establishment of a social order where freedom could be fully institutionalized. On the path opened up by Adam Smith, Emile Durkheim and John Dewey, Honneth sees in each of those social spheres positive traits, that are often threatened by pathological developments. Such an approach lead his critics to challenge his normative reconstruction of modernity's normative principles, particularly the sphere of market capitalism, on the grounds that he would have renounced any critical commitment to the transcendence of the existing social order (Freyenhagen, 2015; Schaub, 2015). 
Responding to such objections, Honneth presents a complementary study to Freedom's Right: the idea of socialism (2015), the goal of this study is not only to reply to those challenges, but also to present a feasible alternative to the current social order, an alternative which Honneth tries to show that was already present in the works of the first socialist theoreticians - from Robert Owen to the young Karl Marx through Charles Fourier, Henri de Saint-Simon e Pierre-Joseph Proudhon. Honneth's goal with this study - beyond defending his own version of a theory of justice - is twofold: On one hand, he tries to present the original idea of socialism as a criticism of individualistic, egoistic tendencies, which emphasises a particular relationship between freedom and fraternity; On the other hand, he tries to correct overly teleological socialist doctrines and their limited economical character, presenting it as a form of democratic experimentation.

The goal of this paper is to analyse the attempt made by Honneth to defend his theory of justice. In order to do that, the article begins by (I) exposing how Honneth moved towards a theory of the implicit institutional context of modern societies. After that (II), some objections to this particular version of his theory will be discussed. Instead of trying to respond to such an objection, this paper will indicate how some authors criticism of Honneth is actually political. This is what forces him to expose the position that will be dealt with in the final section (III). The last section will also offer the opportunity to briefly discuss a distinction made by Honneth in a debate with Jacques Rancière, which is the difference between the concept of an "internal struggle for recognition" and an "external struggle for recognition" (Honneth, 2016).

\section{From reciprocal recognition towards institutional intersubjectivity}

Honneth's aim with Freedom's Right can be expressed as a theory of justice, of which the goal is to reconstruct institutional conditions that uphold the realisation of the main normative value of modernity, namely: freedom. ${ }^{1}$

\footnotetext{
${ }^{1}$ Honneth affirms that freedom as autonomy is the sole ethical value that has so profoundly marked modernity's institutional order. In modern societies, according to him, claims for justice are neither legitimated through the community's will or in relation to any natural order; they are rather related to the individual subject's autonomy. Even equality, so goes Honneth, can only be understood as a realization of the value of individual freedom, for it does not refers to a substantive value ("everyone should be equal"), but to to the fact that the implementation of individual freedom is open to all citizen (2011, p. 35-38). This same situation is mentioned by McBride (2013, p. 113) to conclude differently: According to him, the normative core of all modern theories of justice is the notion that all members of society have universal equal status.
} 
In order to achieve that, the theory of justice should not be encumbered with constructing institutional models; it should rather measure the legitimacy of currently existing institutions regarding the normative potentials inscribed within societal arrangements. The point of departure for the reconstruction of such legitimizing normative arrangements must necessarily take into account the centrality of individual autonomy and consider that fairness is all that protects, promotes and realizes each individual's autonomy within modern societies (Honneth, 2011, p. 40).

However, the very meaning of individual autonomy changes over time, as conceptually as much as socially - as do the presuppositions of individual requirements for autonomy (Honneth, 2011, p 42). According to Honneth, this means that there is a process of complexification of the concept of freedom. Such complexification was reflected by the emergence of a social order in which the necessary conditions for the realisation of freedom became gradually more substantial. If in the $16^{\text {th }}$ and $17^{\text {th }}$ centuries Thomas Hobbes's work served as a reference for the negative definition of freedom, defined as the absence of opposition to individual desires. This also allowed such a definition to take part in the establishment of juridical status of individualism, as well as the notion that all individuals are capable of pursuing their respective interests without external interference. For the theory of justice, such assumptions result in a contractualist tradition, according to which individual wishes regarding one's will would also be projected in a fictional state of nature, so that its starting point is always an atomized being. State sanctioned juridical order thus finds legitimacy through the fiction of a contract among individualized subjects, who for their part have the right to challenge the legitimacy of the State's actions by resorting to their individual interests. Yet, it is not clear how such challenges, disputes and eventual rearrangements could be achieved, since that would call for a different notion of autonomy, namely one that includes a communicative dimension (Honneth, 2011, p. 55). Such new approach would not only include individual wishes but the goals of social agency as a result of autonomy as well. At the root of the notion of self-determination lies the distinction between heteronomous and autonomous grounds for acting, and only the latter are linked to the subject's will. Such a conception would later split into two main traditions. The first one takes authenticity as the expression of free will, whereas the second one gives self-legislation this place; yet, both agree that individual freedom assumes the existence of a free will. According to Honneth, this second approach to the idea of freedom is, in both forms, more complex than that negative approach, for its associated idea of justice includes a higher level of cooperation among subjects. While the first tradition 
utilizes the idea of authenticity and assumes that every subject should be able to publicly express himself without being harmed, the second tradition sees the construction of a general will as a social expression of the idea of selfdetermination (Honneth, 2011, p. 78).

The advantage of such a conception, which Honneth names moral or reflexive, is that in it, the requirements for the realisation of freedom should be given to all members of society. Nevertheless, this conception also meets its limits as a guideline for a theory of justice when it has to make such requirements explicit. This is so because in this approach the conditions to the exercise of freedom are still taken as an external element to freedom itself (Honneth, 2011, p. 79). This limitation is not surpassed, for example, even by Jürgen Habermas' intersubjective reformulation of the idea of self-legislation, for in his communicative theory the assumption that a language as a mediation between subjects means that they are immersed into the social structures of a lifeworld, so that the formulation of rules of action must be met under a fictional collectivity, which would be able to sanction it because every one of its members also took part in that formulation. Yet, the institutional relations that enabled the transformation of "I" in "We" remain lateral to such a model (Honneth, 2011, p. 69-70). Thus, in Habermas' intersubjective take on selflegislation, language appears as an institution of social reality, which should not be seen as an external additive; rather, language should be taken as a mean for the realisation of freedom (Honneth, 2011, p. 81). Honneth's actual intention is to demonstrate, following Hegel, how other institutions could also be conceived as means to the realisation of freedom (Honneth, 2011, p. 84). Only then could freedom be finally characterised as social.

The issue, then, is to find the specific criteria that allow one to differentiate between a free social order from social orders that are not free. The solution could be found on the notion that in the institutions of social freedom the subjects would recognise each other reciprocally. Recognition would be an element of freedom itself: instead of what happens within reflexive freedom, where subjects could formulate rules of action all by themselves (even if those rules were to be applied to social life), when it comes to social life, the pursuit of freedom necessarily finds other people. In this case, any individual must consider that the objective reality, within which she seeks the realisation of her freedom, includes other people with their own interests. The complementarity of both interests reshapes reflexive freedom in such a way that both individuals now reciprocally realize the Other's own goals. Put other wise: they identify themselves and their own goals as a counterpart to the Other. In this sense, freedom now becomes intersubjectively shared. The emergence of such a 
perception of complementarity depends on an additional assumption: that there must also exist institutional practices and routines that regulate the expression of one's own goals as much as her perception of and the articulation of someone else's goals. By such recognitional institutions, subjects learn to identify the complementarity of objective interests they share with other members of society, given their freedom a character that is not merely intersubjective, but social (Honneth, 2011, p. 86). So instead of considering the structures of society as an expression of the conditions to the realisation of freedom, Honneth considers that the conditions for individual freedom are inscribed in the structures (of reciprocal recognition) of social reality. Consequently, within social freedom there is no reconciliation between subjects, but between subjective freedom and objective reality (Honneth, 2011, p.91). By such an extension of the intersubjective character of freedom towards the realm of institutions one could identity a sort of institutional intersubjectivity, that is, the idea that the mediation between the emergence of collective goals is not due to procedural stances; it rather depends on established institutions.

It is at the level of institutional intersubjectivity that the social character of freedom can be properly observed. But Honneth still needs to show how such institutions of recognition are able to instil into the subjects the ability to articulate shared goals and intentions and consequently realise institutional reality's intersubjectivity. It would be necessary to show, at the same time, the conditions to individual freedom and its institutional conditions. So, individual freedom would not be conceptually described, but realistically husked from its own historical conditions of realisation. Here is clear how the Hegelian model finally break off traditional contractualism: By the latter, collective goals shared by individuals are externally imposed always already as goals, whereas by the former is an alignment between the theory and the given historical conditions that allows one to seek within the existing institutions the objectification of pursued interests within a specific context (Honneth, 2011, p. 107). Rather than realistic, such a theory seems to be written backwards, since the historical subjects and the objective arrangements appear as its issues: Instead of constructing institutions of a conceptually fair social order, Honneth's Hegelian project is to be informed from the subjects themselves about how they establish their shared goals.

However, that still leaves open how to articulate and express such intersubjective arrangements. Moreover, such a project still does not make clear why should they be taken to represent a reasonable criterion for a theory of justice. Its advantages - universality and articulation between intersubjectivity and institutional reality - do not indicate why this is fair. The way Honneth 
solves this problem also marks his step from a methodological exposition towards a properly sociological enterprise.

\section{From Critical Theory to the abandon of critique?}

For Honneth, institutional intersubjectivity represents a gain in relation to the former social situation, in which the social order still did not conjugate individual and social interests. A theory of justice proper to that order would add collective institutions to subjects interests rather as an external element. Thus, social freedom represents a higher degree of freedom in comparison to moral freedom because its own internal standards of justice are wider, since they also comprise what Honneth, following Hegel, calls objective reality. Such an historical transition between social orders is not to be understood as a merely evolutionist description; it is rather a theory of history that uses normative criteria to evaluate processes of historical change. ${ }^{2}$ Honneth's method here does not try to anticipate the social order; it rather intents to "analyse whether and how culturally accepted values are in fact realized in the various different spheres of action, and which norms of behaviour ideally prevail [within each sphere]" (Honneth, 2011, p. 121; 2014, p. 64). That is, through a backward look at history, one can observe the development of the social order by following the history, instead of theoretically anticipating it. In such a model, the first criterion of justice is a normative comparison with the previous moment: If a certain social formation is considered to encompass the goals of justice in a wider manner the previously existing forms, that is if its values are more akin to the normative goals associated with justice, then one can speak of progress. Thus, in order to understand social freedom as a specific stage in the notion of justice, Honneth sees that the task of the theory is to show in which measure the social reality matches the shared values and ideals, with which social actors construct collective life's institutions. Hence, the criterion of justice are the pacts social actors establish regarding not only the realization of freedom, but also the conditions to it.

However, this difference regarding the conception of progress deals with only one side of the problem mentioned above: it shows why, from a methodological point of view, social freedom is historically more complete than other forms of freedom. Yet, it still does not answer what criteria is used

\footnotetext{
2 Amy Allen recently presented a distinction between two ways of understanding progress within Critical Theory: The first one, which would be closer to the notion of utopia, would take progress as an historical goal; The second one - in which Honneth is placed - would understand progress as history, hence it would look up for past changes and the widening of normative principles (Allen, 2015, ch. 1).
} 
to measure the articulation of subjective freedom and the institutional context of modern societies. Thus, again referring to Hegel, Honneth affirms that once the realization of freedom results from intersubjective agreements through which universally acceptable conditions to all the concerned are designed, the resulting institutional conditions are also an element of the compromise agreed upon by the subjects and therefore in modern societies justice is measured by the degree, in which individuals are able to take part in those institutions of reciprocal recognition, which mediate such agreements (Honneth, 2011, p. 115). This argument has a circular logic: once modern institutions are more just when they realize reciprocal recognition, agreements mediated by them are the ones that can meet a wider range of interests within society; consequently, wide participation in such institutions is what allows for routines and ideals resulting from them to be legitimized by the individuals; finally, such routines and ideals will be more legitimate, the more they reflect the possibility for the exercise of each individual's autonomy.

It is possible to say that social freedom depends on institutions of reciprocal recognition that allow the largest number of individuals to properly realize their respective individual freedom. Accordingly, practices of social freedom are different from practices associated with other forms of freedom because in the former precisely the shared goals are the horizon within which subjects act. Hence, institutionalized spheres of social action that contribute to the implementation, reproduction and maintenance of such practices are different from the routines related to the merely negative freedom or moral freedom. That is why Honneth rejects the simple identification between the practices of realization of freedom and the formal law; he rather affirms that such practices must be sought after in all those institutional complexes whose structures are based on complementary social obligation (Honneth, 2011, p. 125, 229). ${ }^{3}$ Such institutional complexes, in which he identifies forms of reciprocal recognition, Honneth calls "reality of freedom" - as opposed to the spheres of action that are based respectively on negative or moral freedom, which are the spheres of possibility of freedom. According to him, in modern

\footnotetext{
${ }^{3}$ The space limitations of this article prevent me from discussing the problems resulting from the social overweight of legal freedom as an overjuridification of social practices, which are exposed by Honneth as social pathologies. For criticism of Honneth's exaggeration of the egoistic character of right, see Scheuerman (2017, p. 117). Interestingly enough, social pathologies linked to the sphere of negative freedom have a different structure in comparison to those pathologies associated with moral freedom in that the former are stiffened forms of egoism whereas the latter are distorted realization of values. A comparison between the social effects of each type of social pathologies seems an interesting path to be followed somewhere else, for the first form of social pathology seem more prejudicial to the collective, while the second type rather hampers the possibility of socialization.
} 
interpersonal relationships (be it as friendship, intimate relationships or within the family) there exists a core complementarity of the roles in which a person materially or emotionally contributes to the other's self-realization through the satisfaction of the latter's needs and desires; in economic relations within the market (be it as commodity consumption or as working relations) the complementarity of goals is expressed through the communicative information of needs that could be satisfied by somebody else's practical activity of something; finally, in the democratic public sphere and in the State, citizens assume both roles of speaker and listener as they try to solve problems of the collective ordering of life (examples of each of these complexes, see Honneth, 2011, p. 270, 357, 500).

From this point on, Honneth proceeds the historical reconstruction of the respective process of institutionalization of each of those spheres of mutual recognition; likewise, he also presents a specific diagnosis regarding the actual implementation of practices and routines of social freedom within each sphere. Honneth's diagnoses are rather uneven: he discovers positive tendencies in the sphere of personal relationships, as exemplified by the care about the subjective well-being of every member of the modern family (Honneth, 2011 , p. 295), but he also identifies a tendency for the deregulation and atomization within neoliberal forms of economic relations (2011, p. 468) and also a generalized distrust regarding the representative character of the State, particularly acute when the latter falls prey to lobbyist powers and interests of financial corporations $(2011$, p. 608). It is worth noting that, despite all the difference in the diagnoses internal to each sphere of recognition, Honneth can designate current existing practices as more or less adequate only in regard to the respective criteria of complementarity of each one of them. So, within each of those institutional spheres it is necessary to look for the level of realization of its legitimating principle. The comparison between the promise embodied in that organizing principle and its objective realization not only permits that some practices and social customs appear as deviances or false developments (Honneth, 2011, p. 230), but also allows the theory to critically look over the social reality (Honneth, 2011, p.28). Accordingly, reconstructive criticism would have a more sociological than transformative character.

One of the main objections raised against Freedom's Right refers to the fact that critical alternatives to the capitalist order would have lost importance. Criticism seem to refer to the acceptance of the modern order in general, but they privilege the discussion about the capitalist market. For instance, in Jörg Schaub's comments, Honneth's methods, normative reconstruction, is charged of leaving aside defining traces of Critical Theory, such as "forms of radical 
critique and normative revolutions as well as [the ability to] avoid focusing exclusively on those norms that are already underlying existing, reproductively relevant institutions" (Schaub, 2015, p. 108). The very idea of a "normative revolution" is found by Schaub in Honneth's description of the transition from pre-modern to modern, democratic societies, when the traditional concept of honour is substituted by a democratized and egalitarian principle. ${ }^{4}$ For Schaub, this transition represents a normative revolution, and processes worth such a name are those expressing radical criticism, that is, a sort of criticism that appeals to norms that do not underlie currently existing institutions (Schaub, 2015, p. 108). Normative reconstruction, on the contrary, would be a peculiar sort of internal criticism that is compromised with particular norms underlying currently existing institutions and consequently would merely evaluate the measure in which those institutions realize the normative promises they themselves offer; this is why the reconstructive method would only be able to reckon historical progress that is achieved gradually, for its criticism of social practices refer rather to the form they realize formerly institutionalized promises. The consequence of such a method is that it is compromised with progressive practices that are already part of the institutional framework of a given society, thus excluding criticism that pledge for an absolute change of such institutions (Schaub, 2015, p. 111-112).

More specifically, Schaub argues that Honneth seems to consider that liberal capitalist society would have a (historically unlikely) historical pre-eminence; that, for its turn, would normatively exclude revolutionary possibilities, so that Honneth's affiliation to a tradition of transformative criticism becomes arguable (Schaub, 2015, p. 118). Similarly, Fabian Freyenhagen affirms that once Honneth attributes historical value to the existing institutions, that would imply that, to the concerned subjects, such institutions would appear as "the most progressive there have been" (Freyenhagen, 2015, p. 141). This Honnethian assumption would ignore the notion - central to Critical Theory of the criticism of false consciousness, which could drive subjects to actively support institutions as they actually exist. To Freyenhagen, a charitable (2015, p. 140) reading of Honneth's work would show that the latter's criticism of false consciousness is limited to his interpretation of social pathologies taken as false understandings of the conditions to social freedom. Such a reading, however, does not seem to Freyenhagen to amount to a structural part of Honneth's

\footnotetext{
${ }^{4}$ Honneth never uses the term "normative revolution". He rather affirms that the transition from pre-modern to modern societies represents a revolution in the moral order of society (cf. Fraser and Honneth, 2003, p. 140).
} 
theory of justice's architecture, for the method employed by him implies that an institutionalized established historical stage is better than its predecessors. Yet, methodologically Honneth would himself be a victim of ideology and false consciousness, once he discharges transformative criticism on the basis that no alternative to market capitalism is available nowadays. This would finally show Honneth's "reformist commitment" (Freyenhagen, 2015, p. 142). The end result is a Critical Theory that is shaped by that which currently exists instead of looking for that which hides behind social reality. And consequently Honneth explains social reality in a manner that preclude the problems caused by social pathologies to be solved through revolutions. At the end of the day, he would end up politically compromised with a reformist theory - a theory that abandons the very cornerstones of Critical Theory - thanks to his method of attributing legitimacy to the subject's desires of assuring and reproducing currently existing institutions.

Once Honneth $(2015$, p. 12) assumes that one of the reasons to refine his approach were the criticism of his commitment to a theory devoid of criticism of social reality, it is in his answer that one can better understand the development of the project started with Freedom's right.

\section{The properly social society}

It should not go unnoticed that Honneth's response to the criticism of his supposed reformist commitment with market capitalism comes through a reformulation of the normative idea of socialism, characterized by him as an "intellectual challenge that would permanently accompany capitalism" (Honneth, 2015, p. 11) but that - thanks to the spreading of fetishistic conceptions of social relations, which block any outrage towards current inequalities and which empty transformative utopia - lost his inflammatory potential $(2015$, p. 20$)$, calling then for a conceptual reformulation that could make it again adequate for the present time.

This reformulation, which could only be achieved in a post-Marxist form (Honneth, 2015, p. 87) intent to avoid three congenial errors of the socialist doctrine that were present in the thought of every one of its first representatives since the beginning of the $19^{\text {th }}$ century. The first mistake is summarized as the generalized assumption that the greatest hindrance to the overcoming of capitalism is limited to the economic sphere - thus keeping a blind eye to the democratic sphere of popular sovereignty as a form of self-determination; consequently, for the first socialists there is a closure of the possibility of characterizing the then emerging social order as a democratic negotiation of independent shared interests, in which individual autonomy and the 
intersubjective construction of the general will are independent of the subject's economic position (Honneth, 2015, p.62). The second mistake refers to the assumption that the interests of the socialist doctrine refers to a practical intent that would already be objectively given, so that not only social actor's interests are pre-determined by the theory, but that very theory falls prey to an arbitrary determination of those interests; consequently, a sociological demonstration of the arbitrariness of the association between proletariat and the interest in the overcoming of capitalism strips the idea of socialism from its claim of being a theoretical expression of an objective movement (Honneth, 2015, p. 71). The third mistake is the assumption that the overcoming of capitalism by socialism would be a historical inevitability deemed to occur thanks to History's own internal dynamics; consequently, human history is presented from the viewpoint of a crisis within the system and not as a collection of challenges to the established social relations that result in experiments worth trying and completing (Honneth, 2015, p. 78). In his attempt to reformulate the socialist doctrine, Honneth tries to normatively correct those mistakes, and for that he exposes a model of Socialism as social experimentalism, in which a connection between forms of freedom and social reproduction could be established ${ }^{5}$ (Honneth, 2015, p. 54). Already in his objection to the economicist and teleological character assumed by the socialist doctrine, one can devise Honneth's answer to his critics: To him, the shortcomings of the theoretical development of socialism block the original idea there contained of a community based on solidarity, in which conditions of freedom would be determined by social cooperation and active participation in the realization of other's subject's desires (Honneth, 2015, p. 47), that is, on social freedom. In order to show that this is the core thesis of the socialist doctrine, Honneth resorts to the investigation of what the early socialists presented to the world.

It is the supporters of Owen in England and Fourier in France that, at the beginning of the $19^{\text {th }}$ century, first used the term "socialism" as a futureoriented concept and charged with political intentions, that served the goals of collective associations who intended to make society's conditions properly social (Honneth, 2015, p. 24). Honneth identifies the impulse for the criticism of the capitalist order in this idea of making society properly social. This impulse, which first gained its moral expression in the principles of the French Revolution - Liberty, Equality, Fraternity - guide every and any project of social improvement; also it is to those principles that the first theoreticians

\footnotetext{
${ }^{5}$ For a discussion about the project of democratic experimentalism, see Alessandro Pinzani's (2016) review.
} 
and activists who used the name Socialists attached to their intentions. This means, contrary to pre bourgeois times, in which social improvements could be devised independently from politics, that those thinkers "could evoke already institutionalized, universally believed upon principles and derive consequences from then" (Honneth, 2015, p. 26). The most diverse proposal carried by the different socialist streams are unified by one of those radical consequences: the cause for the injustice that chastens the working classes is to be found in the circumstance that the capitalist labour market escapes any social constraint and hence follows its own internal law of supply and demand. According to Honneth, this interpretation, which was first formulated by Emile Durkheim, sees in the claim for a social reembedding of the market, a normative dimension that is more profound than the political goal of the distribution of goods: the assumption that the means of production to a social logic would represent a necessary assumption to the moral exigence of connecting freedom and fraternity. Thus it is the principle of individual freedom that seems way too narrow, for in its egoistic form it would represent a contradiction to the solidary principle of fraternity (Honneth, 2015, p. 30-33). However, it is only with the second wave of socialist writers, like Louis Blanc and Proudhon, that such criticism of private egoism is crystallized: in their writings one can find the idea that the socialization of the means of production serves the moral objective of withdrawing the revolutionary promise of freedom and the character of a mere prosecution of private interests and thus unifies it with fraternity through unforced cooperation. Therefore, it is not the promise of a whole new order that is central here; rather the possibility of creating an institution out of it (Honneth, 2015, p. 33).

It is in the work of the young Marx that Honneth sees the conceptualization of such critical intuitions about private egoism. Therefore, instead of the acknowledgement of other subjects as individual beneficiaries of market mediated interaction (thus, not properly dependent on each other), Honneth finds the image of a society in which individuals recognize already in their own activities and intentions, someone else's needs (Honneth, 2015, p. 42). With this change, instead of an imperative for the maximization of one's own opportunities within the market, prevails a form of reciprocity as being for the other. Thus, the first socialists marry the idea that freedom only can be unlimited when the realization of individual goals within society finds agreement for each of its members - and precisely because of that society is realized through reciprocity (Honneth, 2015, 45-46). Such expansion of the notion of freedom is based on a "holistic individualism" (2015, p. 47) which is more than a robust notion of solidarity, according to Honneth. Rather, freedom 
is not conceived with regard to the individual person, but to the collective that propitiate and realize individual freedom, that is, freedom is now social freedom (2015, p. 48).

Despite such fruitful core assumption, the socialist movement ended up imprisoned within those congenial errors, according to Honneth. The most relevant thing here is to note that his rebuttal of the criticism of his reformist compromise is exposed as a demonstration that the most endurable immanent criticism to the capitalist order is based on the conceptual vocabulary of social freedom: Internal criticism of the capitalist order would not be addressed to the revolution of a normative order; rather it would demand to make it properly social. Key here is to understand a social order's legitimacy's principles and the conflicts about their meanings. This last point is made especially clear during a debate between Honneth and Jacques Rancière.

According to Rancière, Honneth's model of a struggle for recognition proceeds to the identification of pre-existing entities. Even as a criticism of the existing order, it is still based upon subjects that can question the harm done to their identities, but not every form of inclusion (Rancière, 2016, p. 85). ${ }^{6}$ As an answer to that objection on his own theory's critical potential, Honneth goes back to the idea that, since the legitimizing principles of any social order are always open, it is possible to distinguish between two types of social struggle. The first one would be that, which results in a new interpretation and aims at convincing the concerned of the validity of its arguments through an interpretative dispute; as long as it does not have as its goal an interruption of the social order, such a struggle questions modes of interpretation of a given social order's implicit principles. This is an internal struggle for recognition. The second type of political intervention relates to the interruption of the normative order and the destruction of its authority. This is the one, with different levels of subtlety, that Rancière, Freyenhagen and Schaub favour in their arguments. Such intervention would happen, according to Honneth's reading, when a given group finds itself incapable of expressing themselves or presenting their demands within the given communicative norms. Such struggle for external recognition, or revolution, not only is less frequent than the other type of political intervention. Its architecture does not call for the investigation of everyday causes for revolt and political subversion that do

\footnotetext{
${ }^{6}$ Rancière's criticism to the identification of the theory of recognition with that, which is already existent is related to his idea that the moment of the political is the creative moment, in which the share of the sensitive (that is, of the actual forms of sociability) is challenged in order to permit the reframing of that social world based on its disclosure to that which is new. Unfortunately I cannot develop with the necessary attention a discussion on The Frenchman's theory here.
} 
not claim to revolutionize the whole social order (Honneth, 2016a, p. 106). For those little projects of re-appropriation and reinterpretation, Honneth concludes that the model of a theory of justice as social analysis is, indeed, more adequate.

\section{Conclusion}

Defending his model of a theory of justice that is socially anchored, Honneth tries to link the apparently more radical idea of socialism, without denying its capitalism-critic character, to a transformed doctrine of postmarxist, ${ }^{7}$ centred around the notion of historical experimentalism. More important, however, is the attempt to associate the normative core of socialism, that is, the criteria that should guide progressive experiences, with the implicit promise of the socialist doctrine that an alternative to the capitalist order should be exposed rather in the control of egoistic tendencies through the emphasis on social cooperation and reciprocity, instead of claiming to be objectively linked to the interests of a given social class. Thanks to this correction of the congenial errors of the socialist doctrine - the idea that the capitalist order of labour market would be defined exclusively through its economic traces, without a democratic counterpart in the political sphere; the identification of an objective interest in overcoming it that would already be present within society; and the assumption of the historical avoidance of such overcoming - Honneth's proposition of socialism, beyond the advantage of not being determinist, also does not limits itself to the transformation of the economic market order. On the contrary, it would be open not only to the experience and the interests of the subjects, but also to the politically democratic dimension that should accompany this doctrine. This reformulation, which is post-Marxist and at the same time refers the grounding ideals of the socialist forefathers (and as such pre-Marxist) is based on the demonstration that the idea of social freedom, or institutional intersubjectivity, is actually not a political compromise with the normative state of affairs, as Honneth's criticism would want; it is rather a principle that guides the access to the feelings of injustice and the grounds for indignation. As such, as a theory of justice built from the sociological

\footnotetext{
${ }^{7}$ It would be fair to say that such theoretical errors attributed by him to socialist doctrines do not belong solely to Marxism; moreover, some of them have already been discussed by some Marxist authors. For a discussion on Marxism, post-Marxism and neo-Marxism see, for instance, Bidet and Kouvelakis's (2008) introduction to their book. From an internal viewpoint to Critical Theory, Jean-Philippe Deranty (2013) tries to show that Honneth's theoretical architecture, according to which social struggle revolves around interpretations of norms about the mechanisms of social reproduction, is very close to Marx's work own architecture.
} 
findings - and not from theoretical principles - that is, as a theory of justice that is written backwards, the establishment of institutional conditions for the exercise of freedom would be the criterion, with which social achievements and blockades could be realistically measured. Honneth admits, in his exchange with Rancière, that there may be revolutionary moments, moments of external struggle for recognition, but also affirms that they are not only rare, but thanks to their very nature they tend not to be based upon everyday experiences of outrage and political subversion, which as little as they are, amount the privileged subject of sociology. And this, after all, seem to be the privileged subject of Honneth's large recent project.

\section{References}

ALLEN, Amy. The end of progress: decolonizing the normative foundations of Critical Theory. New York: Columbia University Press, $2016<10.7312 /$ alle17324>.

BIDET, Jacques; KOUVELAKIS, Stathis. Critical companion to contemporary Marxism. Leiden: Brill, 2008.

DERANTY, Jean-Philippe. Marx, Honneth and the contemporary tasks of a Critical Theory. Ethical theory and moral practice, v. 16, n. 4, p. 745-758, $2013<10.1007 /$ s10677-013-9407-6>.

FRASER, Nancy; HONNETH, Axel. Redistribution or recognition? A politicalphilosophical exchange. London: Verso, 2003.

FREYENHAGEN, Fabian. Honneth on social pathologies: a critique. Critical Horizons, v. 16, n. 2, p. 131-152, $2015<10.1179 / 1440991715 Z .00000000044>$.

HONNETH, Axel. Leiden an Unbestimmtheit: eine Reaktualisierung der Hegelschen Rechtsphilosophie. Stuttgart: Reclam, 2001.

HONNETH, Axel. Kampf um Anerkennung: zur moralischen Grammatik sozialer Konflikte. Mit einem neuen Nachwort. Frankfurt am Main: Suhrkamp, 2003 [1994].

HONNETH, Axel. Das Recht der Freiheit: Grundriß einer demokratischen Sittlichkeit. Berlin: Suhrkamp, 2011.

HONNETH, Axel. Die Idee des Sozialismus: Verusch einer Aktualisierung. Berlin: Suhrkamp, 2015.

HONNETH, Axel. Remarks on the philosophical approach of Jacques Rancière. In: Axel Honneth; Jacques Rancière; Katie Genel; Jean-philippe Deranty (orgs.). Recognition or disagreement: a critical encounter on the politics of freedom, equality and identity. New York: Columbia University Press, 2016. p.96-106 < 10.7312/ honn17716>.

McBRIDE, Cillian. Recognition. Cambridge: Polity, 2013.

PINZANI, Alessandro. Resenha de "Die Idee des Sozialismus". Ethic@, v. 15, n. 1, p. 191-200, $2016<10.5007 / 1677-2954.2016$ v15n1p191>. 
RANCIÈRE, Jacques. Critical questions on the theory of recognition. In: Axel Honneth; Jacques Rancière; Katie Genel; Jean-Philippe Deranty (orgs.). Recognition or disagreement: a critical encounter on the politics of freedom, equality and identity. New York: Columbia University Press, 2016, p. 83-95.

SCHAUB, Jörg. Misdevelopments, pathologies and normative revolutions: normative reconstruction as method of Critical Theory. Critical Horizons, v. 16, n. 2, p. 107-130, $2015<10.1179 / 1440991715 Z .00000000043>$.

SCHEUERMAN, William E. Recent Frankfurt Critical Theory: down on law? Constellations, v. 24, n. 1, p. 113-125, $2017<10.1111 / 1467-8675.12218>$.

Received: 2 July 2017

Aproved: 29 Sept. 2017

Correspondent author:

Luiz Gustavo da Cunha de Souza

Departamento de Sociologia e Ciência Política

UFSC, Campus Universitário Trindade

88010-970 Florianópolis, SC, Brazil 